\title{
MANAJEMEN KEARSIPAN ELEKTRONIK
}

Fitria Agustina ${ }^{l}$

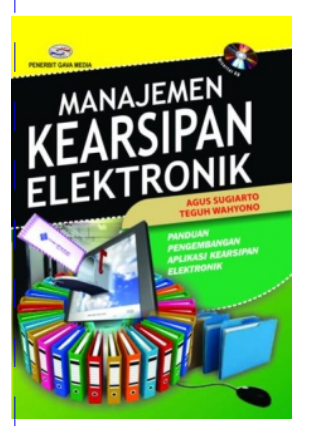

Judul : Manajemen Kearsipan Elektronik

Penulis : Agus Sugiarto dan Teguh Wahyono

Cetakan : ke-1

Penerbit : Gava Media

Tahun : 2014

ISBN : : 979-602-8545-46-4

Halaman : $x+202$ halaman

Perkembangan teknologi dalam aktivitas kantor membawa

informasi dewasa ini berjalan dengan sangat cepat. Pemanfaatan teknologi informasi dilakukan dalam berbagai bidang. Salah satu bidang yang telah memanfatkan teknologi adalah pelayanan administrasi perkantoran. Pengelolaan arsip merupakan salah satu aktivitas yang dilakukan dalam rangka pelayanan administrasi perkantoran. Permasalahan pengelolaan arsip secara konvensional masih sering terjadi. Solusi pengelolaan arsip saat ini adalah dengan memanfatkan teknologi informasi.

Pemanfaatan teknologi informasi dampak terhadap meningkatnya jumlah arsip elektronik yang harus dikelola. Sistem kearsipan elektronik (electronic filing system) merupakan aplikasi yang digunakan untuk mengelola arsip elektronik di kantor. Efektivitas dalam pelayanan arsip dan efisiensi dalam pengelolaan menjadi alasan utama dalam pemanfaatan sistem kearsipan elektronik pada perkantoran modern.

Sistem kearsipan elektronik dirancang dan dibangun berdasarkan konsep manajemen kearsipan secara konvensional. Penemuan kembali arsip dengan cepat, tepat, dan lengkap 
merupakan tujuan utama dalam manajemen kearsipan elektronik. Melalui pengelolaan arsip secara elektronik, diharapkan akan meningkatkan kualitas pelayanan arsip kepada semua pihak, termasuk pimpinan dalam rangka pengambilan keputusan. Melihat fenomena seperti itulah, penulis menyusun buku dengan judul "Manajemen Kearsipan Elektronik".

Buku ini terdiri dari 7 bab. Pembahasannya diawali dengan uraian mengenai manajemen perkantoran modern, konsep pengelolaan arsip secara konvensional dan diakhiri dengan bahasan tentang kearsipan elektronik. Selain itu juga disertai dengan contoh aplikasi yang digunakan oleh Fakultas Ekonomika dan Bisnis Universitas Kristen Satya Wacana (FEB UKSW).

Bab pertama adalah manajemen perkantoran modern yang menjelaskan tentang manajemen yang baik yang dapat diterapkan dalam suatu kantor. Fungsi manajemen yang dapat diterapkan dalam melaksanakan tugas perkantoran adalah fungsi perencanaan (planning), penataan (organizing), kepemimpinan (leading), serta fungsi pengendalian dan pengawasan (controlling). Manajemen perkantoran modern menggunakan perangkat teknologi informasi untuk mengelola informasi. Melalui otomasi kantor, sebuah kantor akan mendapatkan berbagai keuntungan dalam pelaksanaan pekerjaan. Dengan kata lain, penerapan alat-alat modern melalui otomasi, suatu kantor bisa menghasilkan kualitas pelayanan informasi yang lebih baik kepada semua pihak.

Pada bab 2 dijelaskan mengenai peranan arsip dalam manajemen perkantoran. Tugas utama manajemen perkantoran adalah memberikan pelayanan informasi kepada pemangku kepentingan dalam suatu organisasi. Agar bisa memberikan layanan informasi, manajemen perkantoran harus melakukan pengumpulan, pengolahan, dan pendistribusian informasi. Informasi tersebut akan dijadikan bahan dalam proses pengambilan keputusan oleh pihakpihak yang berkepentingan. 
Informasi yang dihasilkan dalam proses administrasi berupa arsip. Arsip memiliki kontribusi yang sangat penting dalam pelaksanaan tugas manajemen perkantoran. Oleh karena itu, arsip perlu dikelola dengan baik dengan manajemen kearsipan agar arsip tersimpan, terpelihara, dan mudah ditemukan kembali apabila dibutuhkan.

Pengenalan tentang manajemen kearsipan dijelaskan dalam bab 3 . Pemahaman beberapa konsep penting dalam kearsipan perlu mendapatkan perhatian dalam pengelolaan arsip, baik secara konvensional maupun secara elektronis. Pemahaman akan pengertian arsip dan jenis-jenisnya sangat diperlukan oleh pengelola arsip. Ruang lingkup manajemen kearsipan meliputi aspek $P O A C$ yaitu singkatan dari planning, organizing, actuating, dan controlling. Manajemen kearsipan merupakan upaya pengelolaan arsip atau dokumen sejak tercipta sampai disusutkan, dengan memperhatikan beberapa asas pengelolaan arsip. Penemuan kembali arsip dengan cepat, tepat, dan lengkap menjadi tujuan utama dalam manajemen kearsipan.

Pembahasan selanjutnya dalam bab 4 adalah pengelolaan arsip secara konvensional. Sebelum membahas tentang manajemen kearsipan secara elektronik, dalam bab ini akan dijelaskan mengenai konsep pengelolaan arsip secara konvensional. Mengapa pengelolaan arsip secara konvensional ini penting? Karena hasil dari pengelolaan arsip secara konvensional ini akan menjadi dasar dalam pengelolaan arsip secara elektronis. Arsip dapat diolah secara elektronis apabila arsip sudah tertata dengan baik.

Dengan membaca bab 4 ini, pembaca akan dapat mengetahui beberapa langkah pengelolaan arsip secara konvensional yang dijelaskan dengan rinci. Uraian langkah-langkah tersebut disertai dengan contoh cara memahami sistem kearsipan yang baik, pengorganisasian kearsipan, prosedur pencatatan, prosedur penyimpanan, cara mengindeks arsip, sistem penyimpanan, sistem pengendalian dan pengawasan, sistem pemeliharaan dan keamanan, serta penyusutan arsip. 
Pada bab 5 dibahas mengenai manajemen arsip elektronik yang diawali dengan pengenalan tentang arsip elektronik. Daur hidup arsip elektronik pada dasarnya sama dengan daur hidup arsip konvensional yaitu dimulai dari penciptaan, penyimpanan dan penemuan kembali, pengolahan, pendistribusian, dan penyusutan. Penggunaan sistem kearsipan elektronik memberikan kemudahan dalam pengelolaan dan manajemen arsip. Dengan membaca pemaparan dalam bab ini, pembaca akan lebih yakin untuk segera bermigrasi menggunakan sistem kearsipan elektronik karena banyak kemudahan yang akan diperoleh. Selain itu, pengetahuan lain yang dapat menjadi pertimbangan sebelum memutuskan menggunakan sistem kearsipan elektronik adalah mengenai media penyimpanan, perangkat yang akan digunakan, dan pertimbangan keamanan dokumen yang dikelola.

Fitur-fitur sistem kearsipan elektronik dipaparkan dalam bab 6 . Sebelum melakukan pengembangan aplikasi kearsipan elektronik, perlu dipahami beberapa hal yang penting untuk proses pengembangan. Pertama adalah pembuatan file arsip elektronik yang dapat dilalukan dengan cara membuat secara langsung melalui aplikasi komputer dan dengan cara pemindahan. Pemindahan arsip dapat dilakukan dengan cara pemindaian (scanning), konversi file, dan importing file. Kedua adalah pertimbangan fitur keamanan aplikasi. Sistem keamanan harus bisa memberikan jaminan bahwa hanya pihak-pihak yang mempunyai otoritaslah yang bisa mengakses aplikasi dan jaringan. Ketiga adalah fitur pengelolaan arsip elektronik yang meliputi input dan pencarian arsip elektronik. Keempat, pendistribusian arsip yang dapat dilakukan dengan cara pembukaan isi arsip di monitor, dicetak, disimpan dalam media lain, atau dikirim melalui jaringan.

Bab ketujuh dijelaskan mengenai pengembangan aplikasi sistem kearsipan elektronik. Tahapan yang dapat dilakukan dalam pengembangan sistem bisa dilakukan dengan berbagai metode. Salah satu metode yang dapat digunakan adalah metode waterfall yang biasa 
digunakan oleh para pengembang software. Tahapan identifikasi dan analisis kebutuhan pengguna merupakan langkah awal dalam proses pengembangan sistem kearsipan. Tahapan selanjutnya adalah melakukan perancangan sistem, arsitektur sistem, dan desain sistem. Langkah berikutnya adalah pengembangan atau pembangunan aplikasi, yang diikuti dengan implementasi dan pengujian sistem kearsipan elektronik. Pengujian sistem bertujuan untuk menemukan kesalahan-kesalahan yang terjadi pada sistem. Contoh aplikasi yang diberikan dalam bab ini adalah aplikasi berbasis web yang digunakan di FEB UKSW. Aplikasi ini digunakan untuk mengelola arsip dinamis terutama arsip aktif berupa surat masuk dan surat keluar. Aplikasi ini mirip dengan Sistem Informasi Kearsipan Dinamis (SIKD) yang dibuat dan dikembangkan oleh Arsip Nasional Republik Indonesia (ANRI).

Buku ini layak dibaca oleh pengelola arsip, arsiparis, tenaga IT, mahasiswa, dan masyarakat umum sebagai referensi dalam rangka melakukan pengelolaan arsip secara elektronis, melakukan pemahaman, dan inovasi pengelolaan arsip kantor melalui teknologi informasi. Menariknya lagi, pada bagian akhir buku ini juga dilampirkan UndangUndang Nomor 43 Tahun 2009 tentang Kearsipan, yang akan semakin memudahkan pembaca untuk memahami konsep kearsipan di Indonesia. Akan tetapi ada beberapa penjelasan yang kurang lengkap, salah satunya yaitu mengenai pemeliharaan dan perawatan arsip. Tidak ada bahasan mengenai cara yang dapat dilakukan untuk memelihara dan merawat arsip. Hal ini penting untuk diketahui oleh pembaca untuk melakukan pemeliharaan dan perawatan arsip sebelum mereka mengelola arsip secara elektronis. Selain itu, penulisan banyak menggunakan simbol-simbol yang kurang tepat bila digunakan dalam buku. Akan lebih baik jika penulis juga memperhatikan pedoman penulisan yang baik dan benar agar buku semakin mudah dipahami, tampilan yang menarik, serta sesuai dengan pedoman. 